\title{
RICE HUSK ASH AS CORRECTIVE OF SOIL ACIDITY(1)
}

\author{
Gláucia Oliveira Islabão( ${ }^{(2)}$, Ledemar Carlos Vahl ${ }^{(3)}$, Luís Carlos Timm ${ }^{(4)}$, Donald Luiz \\ Paul $^{(5)}$ \& Aline Hernandez Kath ${ }^{(6)}$
}

\begin{abstract}
SUMMARY
Rice husk ash (RHA) is a by-product from the burning of rice husk that can have favorable effects on the soil in terms of acidity correction. The objectives of this study were to determine the effective calcium carbonate equivalent (ECC) of RHA under field conditions, and establish technical criteria as a basis for estimating the overall ECC of RHA. The 12 treatments of the experiment consisted of $10 \mathrm{RHA}$ dosages $\left(0,10,20,30,40,60,80,100,120\right.$, and $\left.140 \mathrm{Mg} \mathrm{ha}^{-1}\right)$ and two references, one of which was an absolute control (AC) and the other a plot limed and fertilized according to official recommendations (recommended fertilization - RF). The soil was sampled twice (15 and 210 days after incorporating RHA), in the layers 0.00-0.10 and 0.10-0.20 $\mathrm{m}$, to determine the $\mathrm{pH}\left(\mathrm{H}_{2} \mathrm{O}\right)$ and base saturation $(\mathrm{V} \%)$. The ECC and neutralizing value (NV) of RHA were also determined. The results showed that RHA neutralizes soil acidity, in a faster reaction than conventional limestone, despite a low ECC (around $3 \%$ ).

Index terms: acidity correction, neutralizing value, effective calcium carbonate equivalent.

\section{RESUMO: CINZA DE CASCA DE ARROZ COMO CORRETIVO DE ACIDEZ DO SOLO}

A cinza de casca de arroz (CCA) é produzida a partir da queima da casca de arroz proveniente dos processos de beneficiamento, podendo apresentar efeitos favoráveis sobre a correção da acidez no solo. Os objetivos deste trabalho foram quantificar o poder relativo de neutralização total (PRNT) da CCA em condições de campo e elaborar critérios técnicos que sirvam de base para a estimativa do PRNT das CCAs em geral. O experimento foi constituído
\end{abstract}

\footnotetext{
(1) Part of the Thesis of the first author, Post-Graduation course in Agronomy, Faculdade de Agronomia 'Eliseu Maciel", Federal University of Pelotas - FEAM/UFPel. Received for publication on April 23, 2013 and approved on March 25, 2014.

(2) $\mathrm{PhD}$ in Agronomy (Soil Science), Federal University of Pelotas - UFPel. Campus Universitário, s/n. Postal Box 354. CEP 96001970 Pelotas (RS), Brazil. CAPES Fellowship. E-mail: gislabao@gmail.com

(3) Professor, Department of Soil Science, FAEM/UFPel. E-mail: ledovahl@hotmail.com

(4) Associate Professor, Department of Rural Engineering, FAEM/UFPel. E-mail: lctimm@ufpel.edu.br

(5) Undergraduate student in Agronomy, FAEM/UFPel. Awardee of PROBIC/FAPERGS. E-mail: donald.l.p@hotmail.com

(6) Master's student (Soil and Water Management and Conservation), UFPel. Awardee of CAPES. E-mail: alinecou@gmail.com
} 


\begin{abstract}
por 12 tratamentos compostos por 10 dosagens de CCA equivalentes a $0,10,20,30,40,60,80$, 100, 120 e $140 \mathrm{Mg} \mathrm{ha}^{-1}$ e duas referências, sendo uma testemunha absoluta (TA) e outra com calagem e adubação recomendada (AR). Foram realizadas duas amostragens de solo aos 15 e 210 dias, após a incorporação da CCA, nas camadas de 0,00-0,10 e 0,10-0,20 m para a determinação do $\mathrm{pH}\left(\mathrm{H}_{2} \mathrm{O}\right)$, e da saturação por bases (V\%). Também foram determinados o PRNT e o poder de neutralização $(P N)$ da CCA. Os resultados evidenciaram que a cinza de casca de arroz atua como corretivo de acidez de solo, reagindo mais rápido que o calcário convencional, mas apresentando PRNT baixo, da ordem de $3 \%$.
\end{abstract}

Termos de indexação: correção de acidez, poder de neutralização, poder relativo de neutralização total.

\section{INTRODUCTION}

The burning of rice husk for power generation in industries has generated a new residue consisting of a mixture of ash, charred hull and fresh rice husk fractions. The proportions of these components can vary according to the combustion efficiency, but the residue has been designated by the generic term rice husk ash (RHA). On average, RHA corresponds to $15 \%$ of the mass of the rice husk used in the process (Gonçalves \& Bergmann, 2007) and does, in itself, not represent a high damaging potential for the environment. According to the norms of ABNT (NBR 10004, 2004), RHA can be classified as a nonhazardous and non-inert residue (class II). Nevertheless, since industrial production is concentrated in urban areas, the large residue volume poses a real risk of pollution in these environments.

Intense research has focused on the use of RHA in several branches of economic activity. However, most of these studies have been conducted at the laboratory level, and the resulting scientific knowledge has not yet been translated into appropriate technologies for commercial production (Chandrasekhar et al., 2003). Due to these technological difficulties of a full exploitation of RHA on an industrial scale, its use in agricultural soils seems to be the most reasonable alternative for the disposal of this residue.

Factories offer RHA free of charge to rural producers. Interestingly, although many producers already use RHA on their fields, few studies on this subject have been published and while some producers use the residue indiscriminately, others are rather cautious due to the lack of reliable information. Agronomists of the official extension network have demonstrated the beneficial effects of RHA on the development of crops in the field. But in view of the amounts some farmers apply to the soil, a crucial question arises: what is the threshold dose that can be applied without causing harmful effects to plants and/or soil?

In principle, the threshold dose depends on the effects of RHA on the soil properties. It can increase the $\mathrm{pH}$ and nutrient availability (Silva et al., 2008; Pinto et al., 2009; Sandrini, 2010) and can affect the hydro-physical properties as well. The magnitude of these effects depends on the characteristics of the proper RHA and the soil, the RHA dosage, and the interaction between soil and RHA. Among these effects, the increase in $\mathrm{pH}$ is the most immediate and farreaching for affecting a number of other properties and processes in the soil and can therefore serve as initial guide to determine the threshold dose of a particular RHA a soil can receive. To estimate the effect of RHA on the soil pH, its ability of soil acidity correction must be quantified.

The ability of a material to correct the acidity level is a function of its base content and of the reactivity of these bases in the soil. In limestone, a conventional acidity amendment, the base content is expressed as calcium carbonate equivalent or neutralizing value (NV) and the relative efficiency or fineness factor (FF) is established as a function of the particle size of limestone (Raij, 2011). The smaller the particle size, the faster the solubilization reaction and acidity correction. The NV can be determined in the laboratory by measuring the amount of acid a sample neutralizes and FF can be estimated from the particle size (Tedesco et al., 1995). With these two indices, the ECC (effective calcium carbonate equivalent) (Raij, 2011) can be calculated by the expression: $\mathrm{ECC}=\mathrm{NV} \times \mathrm{FF} / 100$, in which all variables are expressed in percentage. The ECC is the indicator of the capacity of lime to correct acidity, and is used to calculate appropriate soil liming rates.

Basically, the NV of RHA can be determined in the laboratory by the same method as for limestone, measuring the amount of acid a sample can neutralize, but not the FF, since particles with different sizes also differ in chemical composition, opposite to what is assumed as true for limestone. Without knowing the FF, it is not possible to calculate ECC. However, it is possible to estimate ECC of RHA experimentally, comparing the effect of $\mathrm{RHA}$ on the soil $\mathrm{pH}$ with that of a limestone with known ECC. Pinto et al. (2009) evaluated the ECC of a RHA in a factorial experiment in a laboratory, by testing levels of a mixture of $\mathrm{CaCO}_{3}$ and $\mathrm{MgCO}_{3}$ p. a with RHA levels. The resulting ECC value of RHA was $2.78 \%$, which is low and can differ greatly under field conditions. With this experimentally determined value and the analytically determined NV, the FF can be estimated.

The objectives of this study were to quantify the ECC of a RHA sample under field conditions and 
establish technical criteria as a basis for the estimation of ECC of RHAs in general.

\section{MATERIAL AND METHODS}

A field experiment was carried out at the Agricultural Center of Palma, Federal University of Pelotas, in the municipality of Capão do Leão - Rio Grande do Sul (RS) (coordinates E357.860 N6.480.490; UTM zone 22; datum WGS84). The soil of the experimental area is a Typic Hapludult (Severo, 1999) with a sandy loam texture (Table 1). The originally native grassland area was used for five years for oat under conventional management, then revegetated with native grassland plants, and used for dairy cattle grazing in the last five years preceding the experiment.

The experiment consisted of 12 treatments, corresponding to 10 RHA dosages $(0,10,20,30,40$, $60,80,100,120$, and $140 \mathrm{Mg} \mathrm{ha}^{-1}$ ), and two references, one of which was an absolute control (AC) and one a plot limed and fertilized according to official recommendations (recommended fertilization - RF). The RF treatment consisted of liming to achieve $\mathrm{pH}=6.0$ and fertilization for oat, as recommended by the Commission of Chemistry and Soil Fertility of the Southern Regional Center of the Brazilian Society of Soil Science - CQFSRS/SC (2004). The absolute control treatment consisted of maintaining the initial state of the soil, without fertilization and liming and without crops.

The experimental units consisted of $6 \times 4 \mathrm{~m}\left(24 \mathrm{~m}^{2}\right)$ plots arranged in a randomized block design with four replications. Prior to the experiment, the $\mathrm{pH}$ variation was mapped in the experimental area, sampling the soil in a $10 \times 10 \mathrm{~m}$ grid, at a depth of $0.20 \mathrm{~m}$, in order to obtain the lowest possible $\mathrm{pH}$ variation within each block. After this sampling, the entire area was plowed and fenced, constructing two narrow-based terraces to contain the erosion that was visible in the area before tillage.

The RHA used in the experiment came from a company in the region of Pelotas, RS, Irgovel (Vegetable Oil Industry of Rio Grande do Sul). Before distribution to consumers, this RHA was moistened with industrial wastewater to facilitate transportation. The chemical characteristics of RHA are listed in table 2.

The silicon ( $\mathrm{Si}$ ) contained in the RHA was determined by X-ray fluorescence (EDX-720) in a laboratory for analysis and characterization of materials of the Center of Technological Development (CDTec), Federal University of Pelotas, RS. Aside from the $\mathrm{pH}$, carbon was determined by the Walkley-Black method and total $\mathrm{N}$ by the Kjeldahl method, in the chemistry laboratory, Soil Science Department/ UFPel, as described by Tedesco et al. (1995). To determine the $\mathrm{K}, \mathrm{Na}, \mathrm{Ca}, \mathrm{Mg}, \mathrm{Al}, \mathrm{P}, \mathrm{S}, \mathrm{Cu}, \mathrm{Fe}, \mathrm{Mn}$, and $\mathrm{Zn}$ contents, the samples were digested in redistilled nitric acid and hydrofluoric acid (p.a.) and the elements were quantified by inductively coupled plasma optical emission spectrometry (ICP-OES) (Perkin Elmer optima 4300 DV) in the Laboratory of Industrial and Environmental Chemistry - LAQIA, at the Federal University of Santa Maria, RS.

The NV of RHA was determined by the general method described by Tedesco et al. (1995), but using less concentrated $\mathrm{HCl}$ and $\mathrm{NaOH}$. Due to the low NV of the material, the results for RHA were inaccurate, possibly due to the acid and base concentrations underlying the NV of limestone, for which the method is described. After some testing, we adopted the concentrations $\mathrm{HCl} 0.005 \mathrm{~mol} \mathrm{~L}^{-1}$ and $\mathrm{NaOH}$ $0.005 \mathrm{~mol} \mathrm{~L}^{-1}$.

An approximate amount of $18 \mathrm{Mg}$ of RHA was deposited in the experimental area on an uncovered pile alongside the experimental treatments. To facilitate the measurement of the RHA applications in the plots, the rates were converted from dry mass to volume. To this end, the density of RHA in the pile was determined by collecting nine samples randomly at different positions and with different moisture contents. It was found that the moisture content did not affect the density (Figure 1) and an average density of $0.184 \mathrm{Mg} \mathrm{m}^{-3}$ was used in the calculations.

To distribute the RHA on the plots, a wooden box was constructed (exact extent of $0.80 \times 0.60 \times 0.54 \mathrm{~m}$ ), to hold an amount of RHA equivalent to a rate of $20 \mathrm{Mg} \mathrm{ha}^{-1}$. The other rates were multiples and sub-

Table 1. Chemical properties and particle size of the experimental soil in the layers 0.00-0.10 and 0.10-0.20 $\mathrm{m}$

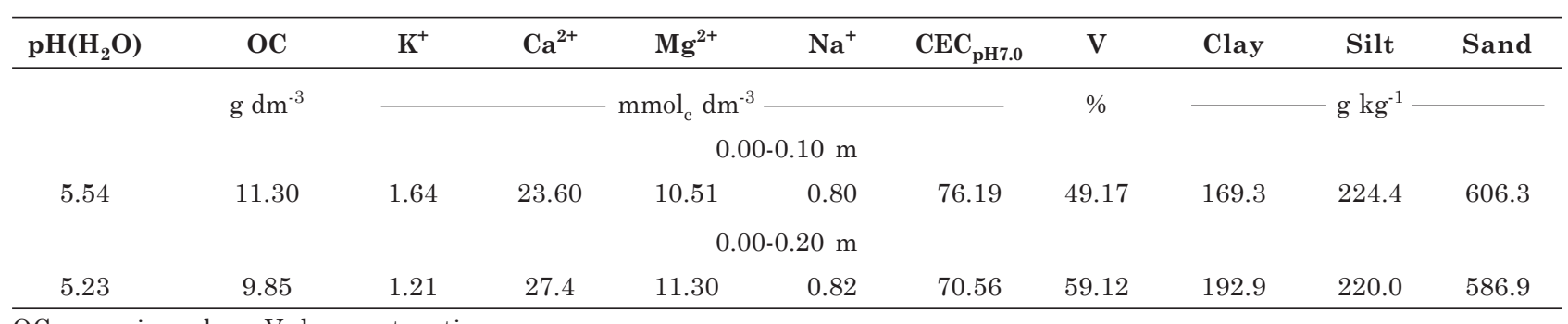

OC: organic carbon, V: base saturation. 
Table 2. Chemical composition of the rice husk ash used in the experiment

\begin{tabular}{|c|c|c|c|c|c|c|c|c|c|c|c|c|c|c|c|}
\hline $\mathrm{pH}\left(\mathrm{H}_{2} \mathrm{O}\right)$ & NV & $\mathrm{Si}$ & $\mathbf{K}$ & $\mathrm{Na}$ & $\mathbf{C a}$ & Mg & $\mathrm{Al}$ & $\mathrm{C}$ & $\mathrm{N}$ & $\mathbf{P}$ & $\mathrm{S}$ & $\mathrm{Cu}$ & $\mathrm{Fe}$ & Mn & $\mathrm{Zn}$ \\
\hline & $\%$ & & & & & $\mathrm{~g}$ & $g^{-1}$ & & & & 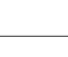 & 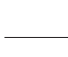 & $-\mathrm{mg}$ & $\mathrm{rg}^{-1}$ & 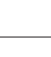 \\
\hline 8.6 & 0.91 & 410.5 & 11.35 & 6.83 & 6.02 & 4.20 & 0.23 & 72.3 & 0.98 & 2.64 & 3.52 & 7.5 & 480 & 1278 & 34 \\
\hline
\end{tabular}

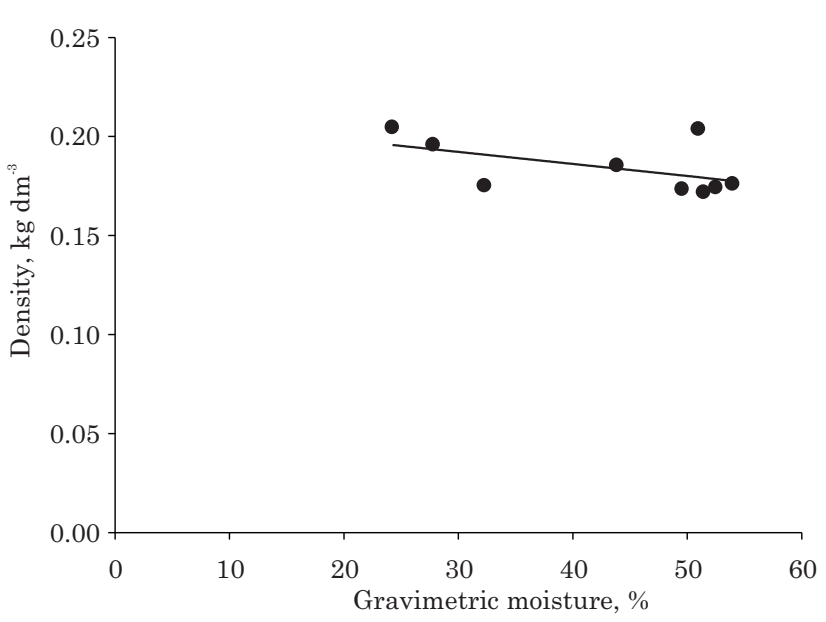

Figure 1. Density of rice husk ash (dry mass at $\left.110^{\circ} \mathrm{C}\right)$ according to the moisture content. ns: nonsignificant by the $\mathrm{F}$ test at $5 \%$.

multiples of the contents of one box. The measured RHA was spread on the surface of each plot and then incorporated into the surface layer $(0.00-0.10 \mathrm{~m})$ with a rotary hoe.

To calculate the liming and fertilization requirements in the corresponding treatment after outlining the experiment, soil samples were collected from the plots of treatment $\mathrm{RF}$, in which $\mathrm{pH}$ was determined in water and the SMP and the extractable $\mathrm{P}$ and K contents by Mehlich-1, as described by Tedesco et al. (1995). In the plots of all blocks, the P levels were classified in the "very low" range and $\mathrm{K}$ in the "medium" range, according to the criteria of interpretation of CQFSRS/SC (2004). The SMP pH values were $6.7,6.6,6.5$ and 6.1 , respectively, in the blocks 1, 2, 3 and 4. With these data, we estimated the lime requirements to reach $\mathrm{pH} 6.0$ as follows: 0 $\left(\mathrm{pH}=5.95\right.$ in this plot), $0.8,1.1$, and $2.7 \mathrm{Mg} \mathrm{ha}^{-1}$ (ECC $100 \%$ ) for the blocks 1, 2, 3, and 4, respectively (CQFSRS/SC, 2004). To meet this requirement, a dolomitic limestone with ECC $=76.2 \%$ was used. Phosphorus and $\mathrm{K}$ were applied to the plots of the $\mathrm{RF}$ treatment at rates of $150 \mathrm{~kg} \mathrm{ha}^{-1} \mathrm{P}_{2} \mathrm{O}_{5}$ as single superphosphate and $80 \mathrm{~kg} \mathrm{ha}^{-1} \mathrm{~K}_{2} \mathrm{O}$ as potassium chloride.

On the same day of incorporating RHA, limestone and fertilizer, black oat (Avena strigosa) was sown (broadcast at $8 \mathrm{~g} \mathrm{~m}^{-2}$ ) and raked into the soil.

The soil samples to evaluate the effect of RHA as acidity corrective were collected in two different times.
The first collection was performed 15 days and the second 210 days after application (daa) of RHA, from the layers 0.00-0.10 and 0.10-0.20 m, in two independent samples. Each sample consisted of six sub-samples per plot collected with a soil column cylinder auger. The samples were dried at $60{ }^{\circ} \mathrm{C}$ to constant weight and loosened by hand with a clod breaker and sieved $(<2 \mathrm{~mm})$ prior to chemical analyses.

In these prepared samples, the $\mathrm{pH}$ was determined in water (1:1), the contents of exchangeable $\mathrm{Na}, \mathrm{K}$, $\mathrm{Ca}, \mathrm{Mg}$ and $\mathrm{Al}$ and titratable $\mathrm{H}^{+}$according to the methods described by Tedesco et al. (1995). Base saturation (V\%) was calculated from the variables analyzed. The ECC values of RHA were estimated from the $\mathrm{pH}$ response curves to the RHA dosage and from the $\mathrm{pH}$ values achieved in the RF treatment.

The data related to the chemical properties were analyzed by means of regressions between variables and RHA dosage, using software Sigmaplot (2004).

\section{RESULTS AND DISCUSSION}

\section{Effect of rice husk ash on soil pH}

The rice husk ash increased the soil $\mathrm{pH}$, in agreement with the results obtained by Pauletto et al. (1990), Pinto et al. (2009) and Sandrini (2010). In the sampling 15 days after RHA application (daa), the increase was clearest in the 0.00-0.10 m layer, in which the $\mathrm{pH}$ reached a value of 7.78 at the highest dose applied, and less pronounced in the $0.10-0.20 \mathrm{~m}$ layer, where the highest RHA dosage induced a $\mathrm{pH}$ of 5.81 (Figure 2a). The sampling carried out 210 daa showed that the effect of RHA on $\mathrm{pH}$ decreased in the surface and increased in the subsurface layer, from the first sampling to the point of no significant difference between layers within each RHA dosage (Figure 2b). In the mean $\mathrm{pH}$ of the two layers, representing the $\mathrm{pH}$ at a depth of $0.20 \mathrm{~m}$, there was no significant difference between the two sampling periods within each RHA dosage. At the highest RHA application $\left(140 \mathrm{Mg} \mathrm{ha}^{-1}\right.$ ), the $\mathrm{pH}$ in the $0.00-0.20 \mathrm{~m}$ layer was 6.65, 15 daa and 6.84, 210 daa (Figure 2c,d).

The effect of RHA on base saturation was consistent with the observed effect on $\mathrm{pH}$ : the $\mathrm{V} \%$ increased with increasing RHA applications. However, the relationship between $\mathrm{V}$ and $\mathrm{pH}$, with the data of 10 RHA dosages, was different between the two sampling periods in the 0.00-0.10 m layer (Figure 3a,b). 
(a)

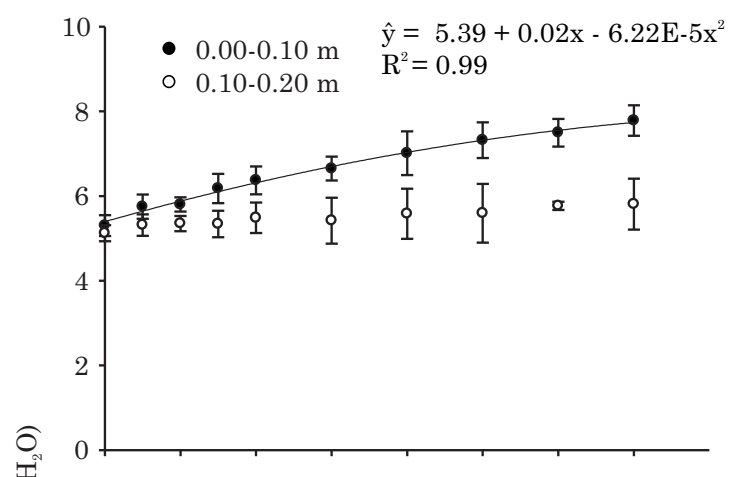

(c)

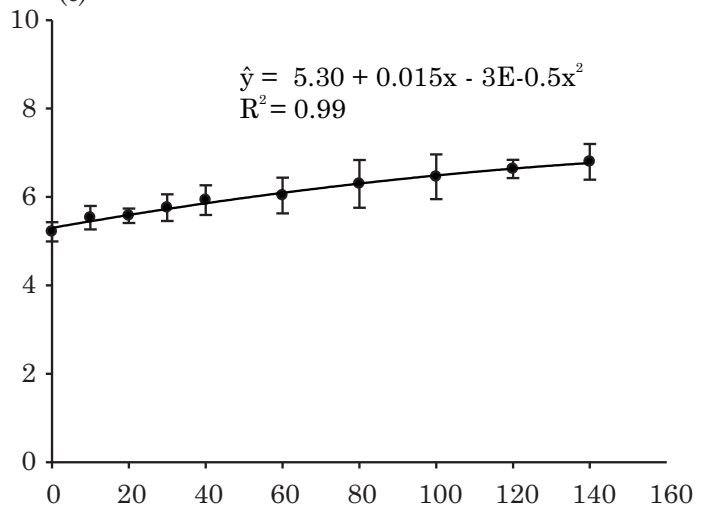

(b)

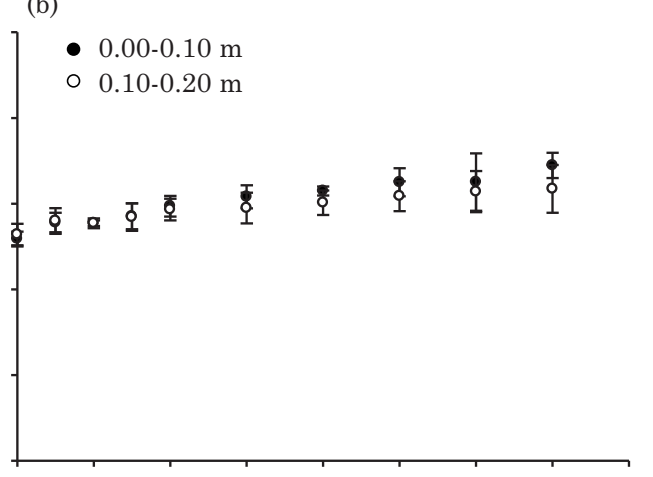

(d)

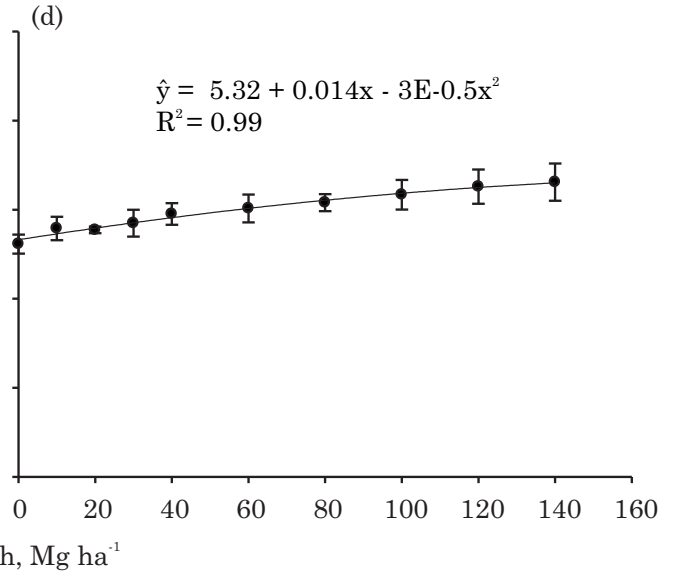

Figure 2. Relationship between dosage of rice husk ash (RHA) and soil $\mathrm{pH}\left(\mathrm{H}_{2} \mathrm{O}\right)$ in the layers 0.00-0.10 and 0.10-0.20 m (a) 15 days after application of rice husk (daa); (b) 210 daa; (c) the average of 0.00-0.20 $\mathrm{m} 15$ daa; and (d) the average of 0.00-0.20 $\mathrm{m} 210$ daa.

In samples collected 15 daa, the $\mathrm{V}$ values achieved in the range of highest $\mathrm{pH}$ values are incompatible for the soils of the region, according to data from Nachtigall \& Vahl (1991). According to these authors, to achieve $\mathrm{pH}$ 6.0, for example, the Typic Hapludult of the experiment should have $\mathrm{a}=85 \%$, but in the first sampling, the $\mathrm{pH}$ was achieved with a base saturation of around $60 \%$ (Figure 3a). In the second sampling, $\mathrm{pH} 6.0$ was reached with a base saturation of around $80 \%$, which is as expected, according to Nachtigall \& Vahl (1991).

The fact that V\% did not increase in the same proportion as the $\mathrm{pH} 15$ days after RHA application (daa) indicates a lack of relation between these two effects. It is possible that the bases could not be dissolved in sufficient proportions in this short period to increase $\mathrm{V} \%$ proportionally to $\mathrm{pH}$. The increases in $\mathrm{pH}$ may have simply resulted from the weighted average of the $\mathrm{pH}$ of the mixture soil-RHA in the 0.00$0.10 \mathrm{~m}$ layer. Hypothesizing that there was no reaction between the RHA and the soil, the $\mathrm{pH}$ of the mixture of the two could be estimated by the weighted average using the volumes and $\mathrm{pH}$ of each component (soil and ash). By this estimation for the highest RHA application (140 Mg ha-1 or $76 \mathrm{dm}^{3} \mathrm{~m}^{-2}$ ), mixed with the surface layer 0.00-0.10 m (soil volume $=100 \mathrm{dm}^{3} \mathrm{~m}^{-2}$ ) and considering $\mathrm{pH}$ values of the soil and RHA of 8.5 and 5.3, respectively, the $\mathrm{pH}$ of the soil-RHA mixture would be 6.68 . This value is practically the same as the $\mathrm{pH}$ measured in the surface layer 15 daa, which was 6.65 . This is consistent with the hypothesis that 15 daa, the basic cations of RHA had not completely reacted in the soil.

\section{Effect of liming on soil $\mathbf{p H}$}

To evaluate the effect of limestone on soil acidity correction, the $\mathrm{pH}$ values of the treatment of recommended liming and fertilization $(\mathrm{RF})$ were compared with the observed values of this variable in the absolute control (AC), in both layers and sampling times, by an independent statistical analysis of the RHA treatments. For this purpose, the data were not included in block 1 , where no lime was applied in the $\mathrm{RF}$ treatment, since the initial $\mathrm{pH}$ was 5.95 in the corresponding plot.

Fifteen daa, limestone had very little effect on the surface layer $0.00-0.10 \mathrm{~m}$ and no effect on the 0.10 $0.20 \mathrm{~m}$ layer, comparing the $\mathrm{pH}$ in $\mathrm{RF}$ with the $\mathrm{AC}$ treatment (Table 3). In the sampling 210 daa, the $\mathrm{pH}$ reached the expected value (6.0) in the surface layer but also increased in the sub-surface layer compared 
to the control and the sampling 15 daa (Table 3). In the average of the two layers, which represents the effect in the 0.00-0.20 m layer, the value was very small until 15 daa, but approached the target $\mathrm{pH} 6$ closely fixed in the establishment of lime rates in the different blocks. This means that the lime actually reacted in the soil and that the $\mathrm{pH}$ was corrected during the 210 daa.

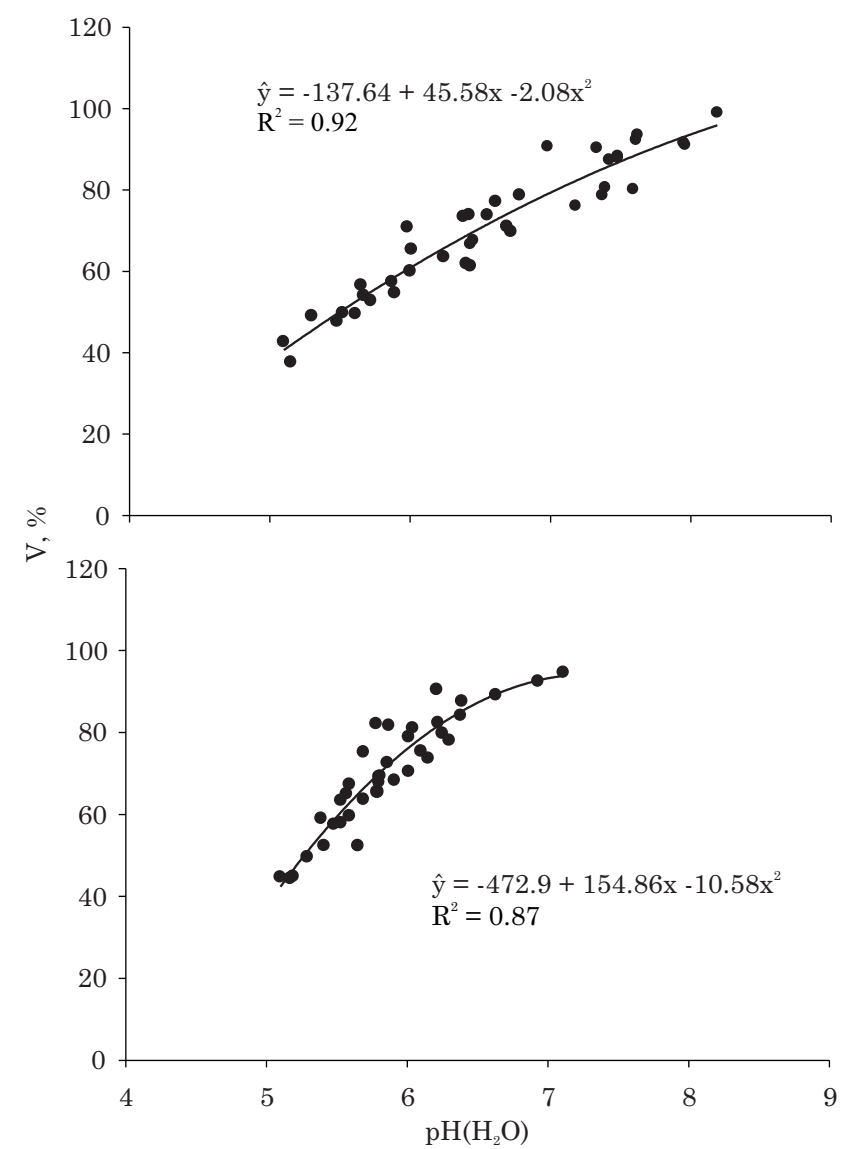

Figure 3. Relationship between base saturation (V) and soil $\mathrm{pH}\left(\mathrm{H}_{2} \mathrm{O}\right)(\mathbf{1 : 1})$ in the 0.00-0.10 $\mathrm{m}$ layer 15 days after application (daa) and 210 daa of rice husk ash in 10 dosages, evaluated in four blocks.

Table 3. pH values in the treatments absolute control (AC) and recommended fertilization and liming (RF) in samples from the layers 0.00-0.10 and 0.10-0.20 m, 15 days after application (daa) and 210 daa after application of rice husk ash. Averages of the three limed blocks

\begin{tabular}{cccccc}
\hline \multirow{2}{*}{ Layer } & \multicolumn{5}{c}{$\mathbf{p H}\left(\mathbf{H}_{2} \mathbf{O}\right)$} \\
\cline { 2 - 3 } \cline { 5 - 6 } \cline { 5 - 6 } & \multicolumn{2}{c}{$\mathbf{A C}$} & & \multicolumn{2}{c}{$\mathbf{R F}$} \\
\cline { 2 - 3 } & $\mathbf{1 5}$ daa & $\mathbf{2 1 0}$ daa & & $\mathbf{1 5}$ daa & $\mathbf{2 1 0}$ daa \\
\hline $\mathrm{m}$ & & & & & \\
$0.00-0.10$ & 5.50 & 5.22 & & 5.78 & 6.07 \\
$0.10-0.20$ & 5.20 & 5.31 & & 5.11 & 5.58 \\
$0.00-0.20$ & 5.35 & 5.26 & & 5.44 & 5.82 \\
\hline
\end{tabular}

The effective calcium carbonate equivalent of rice husk ash

The ECC of RHA used in the experiment can be estimated by comparing the amount of $\mathrm{RHA}$ required to achieve the same effect on the soil $\mathrm{pH}$ as a known dose of limestone with known ECC would have. In the experiment, the lime rate needed to correct acidity in treatment $\mathrm{RF}$ differed between the blocks because each had different acidity, so that a specific response curve of $\mathrm{pH}$ to $\mathrm{RHA}$ dosages was established for each block. With these curves the amount of RHA required to achieve the same $\mathrm{pH}$ as the soil reached in the $\mathrm{RF}$ treatment in the same block can therefore be calculated. This dose can then be compared with the applied lime rate (ECC $100 \%$ ).

It was not possible to estimate the ECC in block 1 where the $\mathrm{pH}$ was already very close to 6.0 , and liming was therefore superfluous. By estimations as described above, the ECC values of RHA varied between the blocks from 2.17 to $3.43 \%$ (Table 4), but the average of $2.89 \%$ is very close to the value $(2.78 \%)$ obtained by Pinto et al. (2009) in the laboratory.

If the NV of RHA is $0.91 \%$, the FF is $317.6 \%$ $[(2.89 / 0.91) \times 100]$. Since the FF is a relative measure of the lime reaction rate, $\mathrm{RHA}$ reacts about three times faster than limestone with particles smaller than 0.3 $\mathrm{mm}$. This is consistent with the observed data. It is not expected that this reactivity varies greatly between RHAs from different sources, because apparently the reactivity of this residue in the soil is not related to the particle size, as in limestones, but to the chemical nature of the bases contained in RHA.

From a practical point of view, it would be unfeasible to perform experiments every time an unknown RHA is used to determine the ECC of RHA. Instead, it can be estimated with a reasonable degree of accuracy using the NV determined in the laboratory, which is a quick and effective procedure, and the value of FF calculated in this work. For practical purposes, the relationship ECC $=3 \times \mathrm{NV}$ could be used.

The NV of the ash used (0.91\%) is far lower than the values reported by Sandrini (2010) and by Chandrasekhar et al.(2003) for rice husk ash (15 and $17 \%$, respectively). The very low NV even made it necessary to reduce the $\mathrm{HCl}$ and $\mathrm{NaOH}$ concentrations to improve accuracy in the analytical laboratory determinations of NV. This shows that the NV of RHA varies widely according to its origin. This variability may be a consequence of the burning temperature, which varies from 500 to $1200^{\circ} \mathrm{C}$ in industries where rice husk is used as energy source, according to Gonçalves \& Bergmann (2007), and of the addition of other residues to the RHA, before being released by the industry.

On the other hand, even the highest cited values of NV of RHA are still much lower than the NV of wood ash cited by other authors, ranging from 22 to 
Table 4. Lime requirement with ECC $=100 \%$ (LR) estimated by the SMP method for $\mathrm{pH} 6.0$ and $\mathrm{pH}(0.00-0.20 \mathrm{~m})$ reached 210 days after liming in the recommended fertilization (RF) treatment plots; equations adjusted to $\mathrm{pH}$ response to the applied RHA doses and ECC of RHA estimated from these data in each replication (block)

\begin{tabular}{cccccc}
\hline \multirow{2}{*}{ Block } & \multicolumn{2}{c}{$\mathbf{R F}$} & Equation $(\mathbf{x}=\mathbf{R H A}$ dosage) & $\mathbf{R}^{2}$ & ECC \\
\cline { 2 - 3 } & $\mathbf{L R}$ & $\mathbf{p H}\left(\mathbf{H}_{\mathbf{2}} \mathbf{O}\right)$ & & & \\
\hline & $\mathrm{t} \mathrm{ha}^{-1}$ & & & & \\
1 & 0 & 5.77 & $\mathrm{pH}=5.60+0.0124 \mathrm{x}-6.10^{-6} \mathrm{x}^{2}$ & 0.93 & - \\
2 & 0.8 & 5.81 & $\mathrm{pH}=5.30+0.0157 \mathrm{x}-5.10^{-5} \mathrm{x}^{2}$ & 0.92 & 2.17 \\
3 & 1.1 & 5.72 & $\mathrm{pH}=5.22+0.0161 \mathrm{x}-6.10^{-5} \mathrm{x}^{2}$ & 0.94 & 3.07 \\
4 & 2.7 & 5.95 & $\mathrm{pH}=5.17+0.0107 \mathrm{x}-1.10^{-5} \mathrm{x}^{2}$ & 0.96 & 3.43 \\
\hline
\end{tabular}

$92 \%$, with an average of $43 \%$ (Risse, 2013). The difference in NV between rice husk ash and wood ash may be due to the high silica $\left(\mathrm{SiO}_{2}\right)$ content of the former (around $90 \%$ ). The high silica content dilutes the concentration of all other components, including that of the bases. The mean contents of $\mathrm{Ca}, \mathrm{Mg}, \mathrm{K}$, and $\mathrm{Na}$ in wood ash cited by Nkana et al. (2002), Ozolincius et al. (2005), Lima et al. (2009), and Risse (2013) are much higher than in the RHA in this study (Table 1) or those cited elsewhere, by Chandrasekhar et al. (2005, 2006), Gonçalves \& Bergmann (2007), Pauletto et al. (1990) and Prasad \& Pandey (2012). Undoubtedly, the fraction of each cation in the form of base, salt or adsorbed to negative charges of solids present in the ash varies between the materials.

The high reactivity of RHA, with an immediate increase in soil $\mathrm{pH}$ after its incorporation, is similar to that reported for wood ash by several authors, for example by Demeyer et al. (2001). According to this author, during wood combustion organic compounds are mineralized and basic cations are converted to their oxides, which can be slowly hydrated and carbonated by exposure to atmospheric conditions after burning. According to Ulery et al. (1993), the K and $\mathrm{Na}$ oxides, which are mainly responsible for the neutralizing power of the acidity of wood ash, are very soluble and do not persist for long in the soil. Assuming that $\mathrm{K}$ and $\mathrm{Na}$ contained in the RHA used in this study were in the form of their oxides $\left(\mathrm{K}_{2} \mathrm{O}\right.$ and $\left.\mathrm{Na}_{2} \mathrm{O}\right)$, the NV calculated from $\mathrm{K}$ and $\mathrm{Na}$ contents (Table 2) would be $2.99 \%$, which is three times higher than the measured value. Therefore, it is plausible that these oxides are responsible for the NV of the RHA used. The levels of these two oxides would be sufficient to explain the effect of $\mathrm{pH}$ on the RHA but insufficient to affect base saturation in the soil in detectable amounts. The cations that promoted higher base saturation in the second sample than in the first could be derived from salts of low solubility and which, therefore, were not solubilized in the first sampling but were in the second. This would explain the increase in $\mathrm{pH}$ already in the first sampling, 15 daa, without the side effect of increased base saturation. An increase in this saturation occurred only 210 daa, a period long enough to solubilize the salts.

\section{CONCLUSIONS}

1. Rice husk ash serves as a corrective of soil acidity. It reacts much faster (with a reactivity of about $300 \%$ ) than conventional limestone, but has a low effective calcium carbonate equivalent (around $3 \%$ ), due to the very low neutralizing value (around $1 \%$ ).

2 . The neutralizing value of rice husk ash can be determined in the laboratory by the method described by Tedesco et al. (1995), though with a lower concentration of hydrochloric acid and sodium hydroxide $\left(0.005 \mathrm{~mol} \mathrm{dm}^{-3}\right)$.

\section{ACKNOWLEDGEMENTS}

The authors are indebted to the National Council for Scientific and Technological Development (CNPq) and Brazilian Federal Agency for Support and Evaluation of Graduate Education (CAPES), for funding and for scholarships.

\section{LITERATURE CITED}

ASSOCIAÇÃO BRASILEIRA DE NORMAS TÉCNICAS ABNT. Classificação de resíduos, NBR 10004. Available at: <http://www.aslaa.com.br/legislacoes/ NBR\%20n\%2010004-2004.pdf>. Accessed: Nov. 10, 2012.

CHANDRASEKHAR, S.; SATYANARAYANA, K.G.; PRAMADA, P.N. \& RAGHAVAN, P. Processing, properties and applications of reactive silica from rice husk - an overview. J. Mater. Sci., 38:3159-3168, 2003.

CHANDRASEKHAR, S.; PRAMADA, P.N. \& PRAVEEN, L. Effect of organic acid treatment on the properties of rice husk silica. J. Mater. Sci., 40:6535-6544, 2005.

CHANDRASEKHAR, S.; SATYANARAYANA, K.G.; PRAMADA, P.N.\& RAGHAVAN, P. Effect of calcination temperature and heating rate on the optical properties and reactivity of rice husk ash. J. Mater. Sci., 41:79267933, 2006. 
COMISSÃO DE QUÍMICA E FERTILIDADE DO SOLO RS/SC - CQFSRS/SC. Manual de adubação e calagem para os estados do Rio Grande do Sul e Santa Catarina. 10.ed. Porto Alegre, Sociedade Brasileira de Ciência do Solo, Núcleo Regional Sul, 2004. 400p.

DEMEYER, A.; VOUNDI, N. \& VERLOO, M.G. Characteristics of wood ash and influence on soil properties and nutrient uptake: an overview. Bioresour. Technol., 77:287-285, 2001.

GONÇALVES, M.R.F. \& BERGMANN, C.P. Thermal insulators made with rice husk ashes; Production and correlation between properties and microstructure. Const. Build. Mater., 21:2059-2065, 2007.

LIMA, R.L.S.; SEVERINO, L.S.; ALBUQUERQUE, R.C.; FERREIRA, G.B.; SAMPAIO, L.R. \& BELTR ̃̃O, N.E.M. Capacidade da cinza de madeira e do esterco bovino para neutralizar o alumínio trocável e promover o crescimento da mamoneira. R. Bras. Oleag. Fibr., 13:917, 2009 .

NKANA, J.C.V.; DEMEYER, A. \& VERLOO, M.G. Effect of wood ash application on soil solution chemistry of tropical acid soils: Incubation study. Bioresour. Technol., 85:323-325, 2002.

NACHTIGALL, G.R. \& VAHL, L.C. Dinâmica de liberação de potássio dos solos da região sul do Rio Grande do Sul. R. Bras. Ci. Solo, 15:43-47, 1991.

OZOLINCIUS, R.; VARNAGIRYTE, I.; ARMOLAITIS, K. \& KARLTUN, E. Initial effects of wood ash fertilization on soil, needle and litterfall chemistry in a Scots pine (Pinus sylvestris L.) stand. Forestry, 11:59-67, 2005.

PAULETTO, E.A.; NACHTIGALL, G.R. \& GUADAGNIN, C.A. Adição de cinza de casca de arroz em dois solos do município de Pelotas, RS. R. Bras. Ci. Solo, 14:255-258, 1990.
PINTO, M.A.B.; VAHL, L.C.; ISLABÃO, G.O. \& TIMM, L.C. Casca de arroz queimada como corretivo de acidez do solo. In: CONGRESSO BRASILEIRO DE CIÊNCIA DO SOLO, 32., Fortaleza, 2009. Anais... Fortaleza, SBCS, 2009. CD-ROM

PRASAD, R. \& PANDEY, M. Rice husk ash as a renewable source for the production of value added silica gel and its application: An overview. Bull. Chem. Reac. Eng. Catalysis, 7:1-25, 2012.

RAIJ, B. van. Fertilidade do solo e manejo de nutrientes. 2.ed. Piracicaba, International Plant Nutrition Institute, 2011. 420p.

RISSE, M. Best management practices for wood ash as agricultural soil amendment. Athens, University of Georgia, 2013. (Bulletin, 1142)

SANDRINI, W.C. Alterações químicas e microbiológicas do solo decorrentes da adição de cinza de casca de arroz. Pelotas, Universidade Federal de Pelotas, 2010. 70p. (Dissertação de Mestrado)

SEVERO, C.R.S. Caracterização dos solos do Centro Agropecuário da Palma. Pelotas, Universidade Federal de Pelotas, 1999. 97p. (Dissertação de Mestrado)

SIGMAPLOT. 2004. For windows, version 9.01. Systat Software, 2004.

SILVA, F.F.; BERTONHA, A.; FREITAS, P.S.L.; MUNIZ, A.S. \& FERREIRA, R.C. Aplicação de cinza da casca de arroz e de água residuária de fecularia de mandioca na cultura de aveia. R. Agroneg. Meio Amb., 1:25-36, 2008.

TEDESCO, M.J.; GIANELLO, C.; BIASSANI, C.A.; BOHNEN, H. \& VOLKWEISS, S.J. Análises de Solo, plantas e outros materiais. 2.ed. Porto Alegre, Universidade Federal do Rio Grande do Sul, 1995. 174p.

ULERY, A.L.; GRAHAM, R.C. \& AMRHEIN, C. Wood-ash composition and soil $\mathrm{pH}$ following intense burning. Soil Sci., 156:358-364, 1993. 